\title{
Mulige senskader hos tannhelsepersonell etter kvikksølveksponering
}

\author{
Forekomsten av senskader etter kvikksølveksponering er lav. Tannhelsesekretærer som tidligere har \\ arbeidet med kvikksølvholdig amalgam, har sannsynligvis en økt forekomst av plager og symptomer som \\ kan knyttes til nevrotoksiske effekter. Kvinnelig tannhelsepersonell kan ha en mulig affeksjon av visuell \\ hukommelse.
}

I 2005 tok Brennpunkt-redaksjonen i NRK opp spørsmålet om mulige senskader i nervesystemet og mulige forplantningsskader hos tannhelsepersonell som følge av eksponering for metallisk kvikksølv ved bruk av amalgam som tannfyllingsmateriale. Programmene bygde bl.a. på foreløpige resultater fra en pilotundersøkelse ved Universitetet i Bergen og en den gang upublisert studie fra New Zealand. Senere

\section{«Kvinnelige tannhelse- sekretærer hadde en lett økt forekomst av symptomer og plager»}

programmer har omhandelt saksbehandling i slike saker i NAV og forsikringsselskaper for å få godkjent antatt kvikksølvrelaterte skader som yrkessykdom.

Etter fjernsynsprogrammene og medieoppmerksomheten som fulgte, stilte Arbeidsog inkluderingsdepartementet i 20051 million kroner til rådighet for å undersøke forekomsten av mulige senskader hos tannhelsepersonell etter kvikksølveksponering. Arbeidsmedisinsk avdeling ved St. Olavs hospital og Norges-teknisk-naturvitenskapelige universitet $\mathrm{i}$ Trondheim fikk oppdraget med å foreta nærmere undersøkelser. Vi vil her kort redegjøre for hvilke funn som ble gjort, ettersom saken fortsatt er aktuell.

\section{Forekomst av helseskader}

I en innledende spørreundersøkelse ble bl.a. spørreskjemaet Euroquest benyttet for å undersøke forekomsten av symptomer og helseplager relatert til nevrologisk sykdom, stemningsleie, hukommelse, konsentrasjonsevne, søvn, utmattelse og psykosomatikk (1). Svarene fra 1193 tidligere og nåværende tannhelsepersonell fra MidtNorge ble sammenliknet med dem fra en kontrollgruppe $(2,3)$. Kvinnelige tannhelsesekretærer hadde en lett økt forekomst av symptomer og plager: 2,5\% anførte minst fire symptomer ofte eller oftere mot $0,9 \%$ i kontrollgruppen (4). Beregninger tydet på at $0,5-2,8 \%$ av kvinnelige tannhelsesekretærer kunne ha kognitive senskader som følge av eksponering for metallisk kvikksølv i arbeid. For tannleger av begge kjønn var det ingen økning i rapporterte kognitive plager sammenliknet med en kontrollgruppe med høyere utdanning (5).

Gjennom undersøkelsene og bruk av detaljerte spørsmål om arbeidsmiljøforhold fikk vi innblikk i bruk av kvikksølv i norsk tannhelsetjeneste de siste 50 årene. Undersøkelser av kvikksølv i urin hos norsk tannhelsepersonell foretatt av Statens arbeidsmiljøinstitutt var svært nyttige (6). Det er grunn til å anta at eksponering for kvikksølv har variert betraktelig alt etter hvilke arbeidsmetoder som har vært brukt. Bruk av kobberamalgam syntes særlig å ha gitt de høyeste eksponeringene (7), men også andre tilberedningsmetoder og generelt $s ø l$ har antakelig bidratt.

I en analyse av påliteligheten av svar på spørsmålene om eksponering fant vi at et detaljert spørreskjema kan være vanskelig å fylle ut for mange deltakere. Dette førte til få komplette eksponeringsvurderinger for enkeltdeltakere. Imidlertid var observerte misklassifiseringer hovedsakelig ikke differensielle, mens forekomsten av falskt positive eksponeringsklassifiseringer var høyere enn forekomsten av falskt negative (8).

Som en oppfølging av spørreundersøkelsen foretok vi nevropsykologiske undersøkelser av 91 deltakere. Hos de i utgangspunktet friske personene som ble undersøkt, fant vi ingen sammenheng mellom kognitiv funksjon og antatt grad av tidligere kvikksølveksponering (9). Det var imidlertid en svak sammenheng mellom visse forstyrrelser ved visuell hukommelse og kvikksølvnivåer i urin hos 28 individer der dette var målt (10).

I spørreundersøkelsen fant vi ingen holdepunkter for økt forekomst av lungesykdom, reproduksjonsforstyrrelser eller andre sykdommer. Det var økt forekomst av enkelte misdannelser hos barn av tannhelsepersonell, et funn som var vanskelig å tolke (11). Dette gjorde at departementet i 2008 bevilget nok 1 million kroner til å gjøre en nærmere undersøkelse med data i Medisinsk fødselsregister. Alle fødsler hos 5493 kvinnelig tannhelsepersonell fra hele landet for perioden 1967-2006 fulgt opp og sammenliknet med alle fødsler hos norske kvinner. Det var ingen økning i forekomsten av medfødte misdannelser eller andre uønskede svangerskapsutfall hos tannhelsepersonellet $(12,13)$.

\section{Tidligere undersøkelser}

Tidligere studier av symptomer og nevropsykologiske utfall hos tannhelsepersonell har vist forskjellige resultater (14-16). Pilotunders $ø$ kelsen fra Bergen viste statistisk signifikante forskjeller i angitte symptomer mellom tannhelsesekretærer og hjelpepleiere (17). En studie i New Zealand med 30 års oppfølging av tannhelsesekretærer viste økt forekomst av flere symptomer og at det var flere deltakere som hadde fått utført hysterektomi enn forventet (18). Det er senere også publisert en omfattende dansk litteraturgjennomgang om mulige kognitive skader og forplantningsskader (16) og en registerundersøkelse, som ikke viste økt forekomst av nevrologiske lidelser og nyresykdom (19).

På tross av resultatene fra våre og andres studier er spørsmålet om mulige senskader fra kvikksølveksponering i tannhelsetjenesten fortsatt kontroversielt. Dette kommer

\section{«Eksponering for kvikksølv har variert betraktelig alt etter hvilke arbeidsmetoder som har vært brukt»}

bl.a. frem ved at NAV og Trygderetten åpenbart har hatt vansker i noen slike saker. Det har vært argumentert, både fra NAV, Trygderetten og departementet, at resultatene av våre studier ikke har vært tilstrekkelig klare til å gi et entydig grunnlag for vedtak. 
Dette kunne man etter vårt skjønn heller ikke ha forventet ut fra enkeltstående undersøkelser. Våre studier er rimeligvis beheftet med usikkerhet, dels pga. den store medieomtalen på forhånd og dels fordi vi brukte ett og samme skjema for registrering av både eksponering og mulige skader av eksponering. Vi mener likevel det er påfallende at vår spørreskjemaundersøkelsen viste lav forekomst av forskjellige plager og symptomer ettersom medieoppmerksomheten hadde vært så stor. Andre forhold er diskutert i de enkelte publikasjonene.

\section{Lav forekomst av senskader}

Vår studie er den første til å tallfeste forekomsten av mulige kognitive senskader etter kvikksølveksponering i tannhelsetjenesten. Forekomsten er sannsynligvis lav (4), slik vi tidligere har påpekt i Tidsskriftet (3). Det er også vist at man ikke kan forvente å finne kognitive utfall ved nevropsykologiske tester når man undersøker eksponert tannhelsepersonell som i utgangspunktet er friske. Våre studier gir ikke støtte for antakelser om økt forekomst av misdannelser eller andre uønskede svangerskapsutfall hos tannhelsepersonell. Våre undersøkelser omfattet imidlertid bare opplysninger fra Medisinsk fødselsregister etter 1967. En gruppe ved Ullevål universitetssykehus er nå i ferd med å starte en studie om andre gynekologiske manifestasjoner hos kvinnelig tannhelsepersonell.

\section{Bjørn Hilt}

bjorn.hilt@stolav.no

Ingrid Heggland

Arbeidsmedisinsk avdeling

St. Olavs hospital

og

Det medisinske fakultet

Norges teknisk-naturvitenskapelige universitet

\section{Oddfrid Aas}

\section{Torgunn Qvenild}

Arbeidsmedisinsk avdeling

St. Olavs hospital

\section{Kristin Svendsen}

Institutt for industriell økonomi

og teknologiledelse

Norges teknisk-naturvitenskapelige universitet

\section{Tore Syversen}

Det medisinske fakultet

Norges teknisk-naturvitenskapelige universitet

\section{Inger Melø}

Tannhelsetjenesten

Sør-Trøndelag fylkeskommune

\section{Helge Sletvold}

Trondheim

Undersøkelsene har vært støttet økonomisk av Arbeids-og inkluderingsdepartementet i perioden $2005-10$.
Bjørn Hilt (f. 1949) er spesialist i arbeidsmedisin, dr.med., avdelingssjef ved Arbeidsmedisinsk avdeling, St. Olavs ospital og professor i arbeidsmedisin ved Norges teknisk-naturvitenskapelige universitet. Han har vært prosjektleder for det aktuelle prosjektet fra 2005. Forfatter har fylt ut ICMJE-skjemaet og oppgir ingen interessekonflikter.

Ingrid Heggland (f. 1980) er m.sc. i nevrovitenskap og er ph.d.-student ved Senter for hukommelsesbiologi/Kavli Institute for Systems Neuroscience ved Norges teknisk-naturvitenskapelige universitet.

Forfatter har fylt ut ICMJE-skjemaet og oppgir ingen interessekonflikter.

Oddfrid Aas (f. 1953) er spesialist i arbeidsmedisin og overlege ved Arbeidsmedisinsk avdeling, St. Olavs hospital.

Forfatter har fylt ut ICMJE-skjemaet og oppgir ingen interessekonflikter.

Torgunn Qvenild (f. 1948) er spesialistsykepleier ved Arbeidsmedisinsk avdeling, St. Olavs hospital.

Forfatter har fylt ut ICMJE-skjemaet og oppgir ingen interessekonflikter.

Kristin Svendsen (1951) er professor i yrkeshygiene ved Institutt for industriell økonomi og teknologiledelse ved Norges teknisk-naturvitenskapelige universitet.

Forfatter har fylt ut ICMJE-skjemaet og oppgir ingen interessekonflikter.

Tore Syversen (f. 1945) er dr.philos., professor i toksikologi ved Institutt for nevromedisin,

Det medisinske fakultet, Norges teknisk-naturvitenskapelige universitet. Hans hovedinteresse er spormetaller og spesielt kvikksølvs virkning i nervesystemet.

Forfatter har fylt ut ICMJE-skjemaet og oppgir ingen interessekonflikter.

Inger Melø (f. 1946) er cand.odont. og fylkestannlege i $\varnothing \varnothing r-T r ø n d e l a g$ fylkeskommune. Forfatter har fylt ut ICMJE-skjemaet og oppgir ingen interessekonflikter.

Helge Sletvold (f. 1952) er cand.psychol., spesialist i klinisk psykologi og klinisk nevropsykologi. Forfatter har fylt ut ICMJE-skjemaet og oppgir ingen interessekonflikter.

Litteratur

1. Carter N, Iregren A, Söderman E et al. EUROQUEST-a questionnaire for solvent related symptoms: factor structure, item analysis and predictive validity. Neurotoxicology 2002; 23: $711-7$
2. Hilt B, Svendsen $\mathrm{K}$, Aas $\mathrm{O}$ et al. Eksponering for kvikksølv hos tannhelsepersonell og forekomst av mulige seneffekter. En observasjonsstudie foretat blant tannhelsearbeidere i Midt-Norge. Trondheim: St. Olavs hospital, 2007.

3. Aas O, Hilt B. Tannhelse, kvikksølv og helseskader. Tidsskr Nor Lægeforen 2007; 127: 1671.

4. Hilt B, Svendsen K, Syversen T et al. Occurrence of cognitive symptoms in dental assistants with previous occupational exposure to metallic mercury. Neurotoxicology 2009; 30: 1202-6.

5. Hilt B, Svendsen K, Syversen T et al. Occurrence of cognitive and neurological symptoms in Norwegian Dentists. Saf Health Work 2011; 2: 176-82.

6. Lenvik K, Woldbæk T, Halgard K. Kvikksølveksponering blant tannhelsepersonell. Nor Tannlegeforen Tid 2006; 115: $350-6$.

7. Svendsen K, Syversen T, Melø I et al. Historical exposure to mercury among Norwegian dental personnel. Scand J Work Environ Health 2010; 36: $231-41$

8. Svendsen K, Hilt B. The agreement between workers and within workers in regard to occupational exposure to mercury in dental practice assessed from a questionnaire and an interview. J Occup Med Toxicol 2011; 6: 8.

9. Hilt B, Sletvold H, Svendsen K et al. Eksponering for kvikksølv hos tannhelsepersonell og forekomst av mulige seneffekter. Del II: Oppfølgingsunders $\varnothing$ kelser av et utvalg. Trondheim: St. Olavs hospital, 2007

10. Sletvold H, Svendsen K, Aas 0 et al. Neuropsychological function and past exposure to metallic mercury in female dental workers. Scand J Psychol 2012; 53: 136-43

11. Brevik K. Forekomst av mulige reproduksjonsforstyrrelser blant kvikksølveksponert tannhelsepersonell - en observasjonsstudie foretatt blant tannhelsepersonell i Midt-Norge. Trondheim: Norges teknisk-naturvitenskapelige universitet 2007

12. Heggland I, Irgens $\AA$, Tollånes $M$ et al. Forekoms av misdannelser hos barn og andre uønskede fødselsutfall i en kohort av tannhelsepersonell. Trondheim: St. Olavs hospital, 2009.

13. Heggland I, Irgens A, Tollånes M et al. Pregnancy outcomes among female dental personnel-a registry-based retrospective cohort study. Scand J Work Environ Health 2011; 37: 539-46.

14. Kjuus H. Kvikksølveksponering blant tannhelsepersonell. Oslo: Statens arbeidsmiljøinstitutt, 2005.

15. Clarkson TW, Magos L. The toxicology of mercury and its chemical compounds. Crit Rev Toxicol 2006; 36: 609-62.

16. Bælum J, Pöckel H. Reference document on exposure to metallic mercury and the development of symptoms with emphasis on neurological and neuropsychological complaints. Odense: Odense University Hospital, 2007.

17. Moen B, Hollund BE, Riise T. Neurological symptoms among dental assistants: a cross-sectional study. J Occup Med Toxicol 2008; 3: 10

18. Jones L, Bunnell J, Stillman J. A 30-year follow-up of residual effects on New Zealand School Dental Nurses, from occupational mercury exposure. Hum Exp Toxicol 2007; 26: 367-74.

19. Thygesen LC, Flachs EM, Hanehøj K et al. Hospital admissions for neurological and renal diseases among dentists and dental assistants occupationally exposed to mercury. Occup Environ Med 2011; 68: 895-901.

Mottatt 27.1. 2012, første revisjon innsendt 11.5. 2012, godkjent 6.6. 2012. Medisinsk redaktør Petter Gjersvik. 